\title{
Role of specialized pro-resolving lipid mediators and their receptors in virus infection: a promising therapeutic strategy for SARS-CoV-2 cytokine storm
}

\author{
Chang Hoon Lee ${ }^{1}$ (1)
}

Received: 28 October 2020 / Accepted: 23 November 2020 / Published online: 4 January 2021

(C) The Pharmaceutical Society of Korea 2021

\begin{abstract}
Unexpected viral infections outbreaks, significantly affect human health, leading to increased mortality and life disruption. Among them is the severe acute respiratory syndrome coronavirus 2 (SARS-CoV-2) which emerged as a deadly pandemic, calling for intense research efforts on its pathogenicity mechanism and development of therapeutic strategies. In the SARS-CoV-2 cytokine storm, systemic inflammation has been associated with severe illness and mortality. Recent studies have demonstrated special pro-resolving lipids mediators (SPMs) lipoxins, resolvins, maresins, and protectins as potential therapeutic options for abnormal viral-triggered inflammation. Pro-resolving lipids mediators have shown great promise for the treatment of Herpes simplex virus, respiratory syncytial virus, human immunodeficiency virus, and hepatitis $\mathrm{C}$ virus. Based on this, studies are being conducted on their therapeutic effects in SARS-CoV-2 infection. In this review, we discussed SPMs and reviewed evidence from recent studies on SPMs as therapeutic options for viral infections, including SARS$\mathrm{CoV} 2$. Based on our analysis of the previous study, we argue that SPMs are a potential treatment for SARS-CoV-2 infection and other viral infections. We expect further research on how SPMs modulate viral-triggered inflammation through G-protein-coupled receptors (GPCRs), and chemical stability and druggability of SPMs.
\end{abstract}

Keywords Virus infection - Specialized pro-resolving lipid mediators - Chemerin receptor $1 \cdot$ FPR2/ALX, SARS$\mathrm{CoV} 2 \cdot$ Cytokine storm

Chang Hoon Lee

uatheone@dongguk.edu

1 College of Pharmacy, Dongguk University, Seoul 100-715, Republic of Korea

\section{Introduction}

The unexpected emergence of deadly coronaviruses, severe acute respiratory syndrome coronavirus (SARS$\mathrm{CoV}$ ) and middle east respiratory syndrome coronavirus (MERS- CoV) significantly affected human health, leading to increased mortality and life disruption. Recently, a third highly pathogenic and infectious coronavirus, severe acute respiratory syndrome coronavirus 2 (SARS-CoV-2), emerged as a deadly pandemic calling for intense research efforts on its pathogenicity mechanism and development of therapeutic strategies. Among others, pro-resolving mediators have been investigated as a therapeutic opportunity for treatment and management of SARS-CoV-2; cytokine storm has been associated with severe illness and mortality, with many studies reporting higher concentrations of pro-inflammatory cytokines in severely ill SARS-CoV-2 patients as compared to those with less severe infection. Hence, resolution of inflammation through selective counter-regulation of cytokines has been identified as a potential therapeutic target for SARS-CoV-2. In this review, we discussed the characteristics of specialized pro-resolving lipid mediators (SPMs) that induce the resolution of inflammation and reviewed evidence from recent studies on SPMs as therapeutic options for viral infections, including SARS-CoV-2. We hope that this review will be of great help in guiding researchers who are exploring SPMs as therapeutic targets for viral infections.

\section{Specialized pro-resolving lipid mediators (SPMs)}

Inflammation is an extremely important, self-limiting immune response; however, uncontrolled or unresolved inflammation has been established as a pathophysiological 
mechanism for various diseases including viral infections, and a cause for prolonged homeostasis imbalance. Resolution of inflammation occurs in an overlapping stage dominated by the spatial and temporal biosynthesis of proresolved mediators (Headland and Norling 2015), SPMs, from essential polyunsaturated fatty acids (PUFAs) during inflammation. The SPMs initiate the process of resolution which include restriction or cessation of neutrophil infiltration, counter-regulation of chemokines and cytokines, induction of the neutrophils apoptosis and subsequent efferocytosis (the process by which apoptotic cells are removed by phagocytic cells) by macrophages (Reville et al. 2006), the conversion of macrophages from classically activated (M1) to alternatively activated cells (M2), return of non-apoptotic cells to the vascular system or lymphatic vessels, and the start of the healing process (Fig. 1) (Headland and Norling 2015). These events facilitate proper return homeostasis balance (Serhan and Savill 2005). For a comprehensive review, including structural explanations of SPMs, see reviews (Park et al. 2020; Chiang and Serhan 2017; Lee 2012).

\section{Lipoxins (LXs)}

Lipoxin A4 (LXA4; 5S, 6R, 15S-trihydroxy-7E, 9E, 11Z, 13E-eicosatetraenoic acid) and lipoxin B4 (LXB4; 5S, 14R, 15S-trihydroxy-6E, 8Z, 10E, 12E-eicosatetraenoic acid) were the first lipid SPMs to be discovered (Chiang and Serhan 2017). They are produced from the conversion of omega- $6(\omega-6)$ arachidonic acid (AA) by lipoxygenase (LOX) through unicellular and transcellular biosynthesis pathways. In transcellular biosynthesis, LXs are synthesized by12-LOX derived through platelet-leukocyte interaction while unicellular biosynthesis pathways involve a series of LOXs-15-lipoxygenase, 5-lipoxygenase, and epoxide hydrolase reactions. In addition to the lipoxygenase-initiated biosynthesis, two distinct lipoxins biosynthesis pathways have been elucidated; aspirin-triggered and statin-triggered routes. Aspirin induces the production of a lipoxin named "aspirin-triggered " (AT) 15-epi-LX through acetylation of serine residue of cyclooxygenase-2 (COX-2), acetylated COX-2 transforms AA into 15R-HETE, which serves as a substrate for 5-LOX (Chiang et al. 2005). Statins, widely used as potent cholesterol-lowering agents, have also been found to enhance the conversion of arachidonate to 15-epiLX (Planaguma et al. 2010). Epi-lipoxins, trihydroxy metabolites of arachidonic acid, are 15R-epimers of their respective lipoxins, 15-epi-LXA4, LXA4, and 15-epi-LXB4, LXB4 (Romano et al. 2015).

In vivo biosynthesis of LXA4 is triggered in an acute inflammatory process in which Polymorphonuclear neutrophil (PMN)'s interaction with PGE2 and PGD2 activates 15-lipoxygenase subsequently facilitating LXA4 biosynthesis (Claria and Serhan 1995). In a murine peritonitis model, the maximum level of LXA4 was achieved within 2 hours

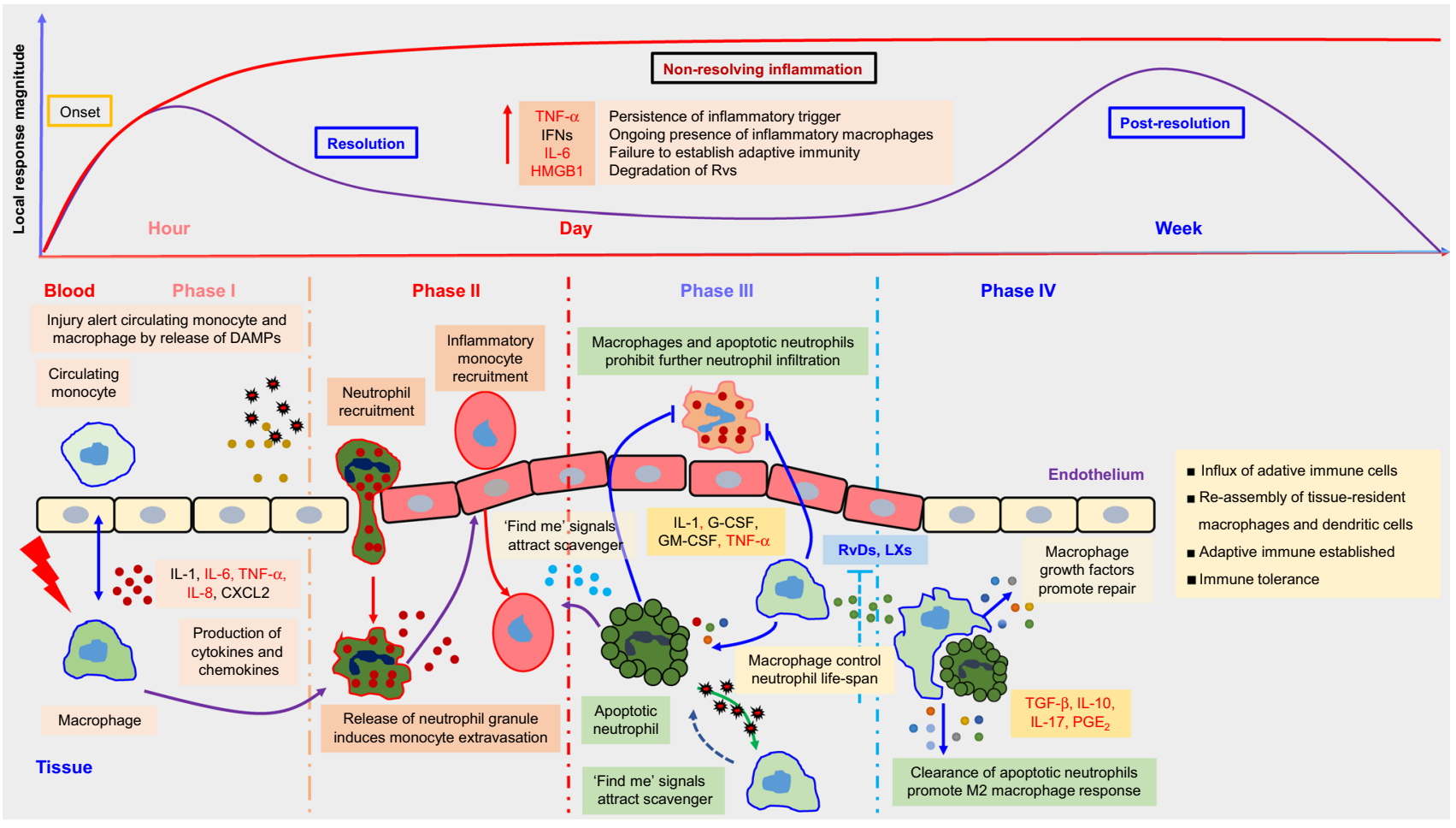

Fig. 1 Inflammation-resolution process. Modified from Fullerton and Gilroy (Fullerton and Gilroy 2016), and Lee et al. (Lee 2018) 
and gradually decreased during the first 24 hours (Bannenberg et al. 2005). The formation of LXs is preserved across a wide range of animal species, from fish to humans (Levy 2005). This indicates the physiological importance of LXs.

\section{E-, D-, and T-series resolvins (Rvs)}

Resolvin ( $\mathrm{Rv})$ is a pro-resolving mediator that is derived from omega-3 fatty acids, primarily eicosapentaenoic acid (EPA), docosahexaenoic acid (DHA), docosapentaenoic acid (DPA), and clupanodonic acid (Duvall and Levy 2016; Serhan et al. 2014). Rvs are divided into several subclasses based on the unique aspects of their structure and/or the straight-chain PUFAs from which they are formed. Resolvin Ds (RvDs) are metabolites of 22-carbon PUFA, DHA. Resolvin Es (RvE) are metabolites of 20 carbons PUFA, EPA; Resolvin Dn-6DPA (RvDn-6DPA) is a DPA isomer, a metabolite of osbond acids; Resolvin Dn-3DPA (RvDn3DPA) is a DPA isomer, a metabolite of clupanodonic acid; Resolvin Ts (RvT) is a metabolite of clupanodonic acid with 17R-hydroxyl residues, unlike RvDsn-3DPA (all have 17S-hydroxyl residues). AT-RvDs, RvD isomers are synthesized by the aspirin-modified COX-2 enzyme to form 17 (R)-hydroxyl rather than the 17 (S)-hydroxyl residue of RvE. Cytochrome P450 enzymes that have not yet been characterized may also form this $17(\mathrm{R})$-hydroxy intermediate and contribute to the production of AT-RvE. All mentioned Rvs except RvDsn-6DPA are metabolites of omega-3 fatty acids (Serhan et al. 2014; Duvall and Levy 2016).

\section{E-series resolvins}

$\mathrm{RvE}$ is a di- or tri-hydroxyl metabolite of EPA. To date, four RvEs (RvE1, 18S-RvE1, RvE2, and RvE3) have been discovered. COX-2, acetylated by aspirin in hypoxic endothelial cells, introduces oxygen groups into 18R-hydro (peroxy)eicosapentaenoic acid (18R-HEPE). Activated PMN uses 5-LOX to convert 18R-HEPE to 5S (6)-epoxy-18R-HEPE, which is further hydrolyzed to RvE1 (Serhan et al. 2000).

$\mathrm{RvE} 2$ is produced by reduction of $18 \mathrm{R}$ HEPE products by 5-LOX to 5S-hydroperoxy, 18-hydroxy-EPE in whole blood (Oh et al. 2012). Unlike RvE1, RvE2 and RvE3 are biosynthesized from 18-HEPE via the 12/15-LOX pathway in eosinophils (Isobe et al. 2012b). Endogenous RvE1 has been shown to accumulate for between 48 and 72 hours, which is a delayed time point of inflammation (Hong et al. 2008). RvE2 appeared at the time point corresponding to initial PMN infiltration in rat peritoneal exudate stimulated by zymosan A and decreased within 24 hours (Isobe et al. 2012a). 18S-RvE1 is produced by 5-LOX and LTA4 hydrolase using 18S-HEPE as a substrate (Oh et al. 2011).

\section{D-series resolvins}

$\mathrm{RvD}$ is a polyhydroxy metabolite of DHA. To date, six RvDs with different positions of cis-trans isomers, as well as the number, position and chirality of the hydroxyl residues have been discovered. D-series Rvs (RvD1-RvD6) are biosynthesized from DHA by the LOX in PMN and macrophages (Serhan et al. 2002). Hydrolysis of peroxide intermediates derived from two LOXs in DHA produces RvD1 and RvD2. On the other hand, the reduction of the peroxide intermediates produces RvD5 (Serhan et al. 2002). In hypoxic endothelial cells in the presence of aspirin, COX-2 converts DHA to 13-hydroxy-DHA or 17R-hydroxy-DHA and activated PMN converts these products to AT-RvD1, AT-RvD2, and other AT-RvD-series. RvD3 and RvD4 are produced through hydrolysis of 4S-hydroperoxy-17S-hydroxy-docosahexaenoic acid, whereas RvD6 is derived from peroxidase of the same precursor.

In a peritonitis model, the in vivo RvD3 levels after zymosan A challenge increases significantly up to 48 hours after inflammation initiation, while RvD1, RvD2, and RvD5 peak at the early stages of the inflammation termination phase (6-24 hours) (Dalli et al. 2013b). RvD3 appears to be produced by a subpopulation of macrophages with high 15-LOX activity (Dalli et al. 2013b). In vivo production of RvD4 in an Staphylococcus aureus injected the dorsal pouch infection model continues for more than 72 hours after sustained release, suggesting that RvD is produced continuously and is under different control from other Rvs (Winkler et al. 2016). RvD6 kinetics have not been reported yet.

\section{Resolvin Ts (RvTs)}

In human platelets, COX-2 pre-treated with aspirin or atorvastatin metabolizes omega-3s, DPA and clupanodonic acid (DPAn-3), to 13S-hydroperoxy forms. Aspirin and atorvastatin change the activity of COX-2 from cyclooxygenase to hydroperoxide-forming enzyme. The intermediates formed are transported to the nearby human neutrophils and perhaps by the activity of the ALOX5 enzyme they are metabolized into four polyhydroxy metabolites: RvT1 (7,13R, 20-trihydroxy-DPAn-3); RvT2 (7, 8,13R-trihydroxy-DPAn-3); RvT3 (7,12,13R-trihydroxy-8Z, 10E, 14E, 16Z, 19Z-DPAn-3); RvT4 (7,13R-dihydroxy-DPAn-3). These four RvTs are formed by human neutrophils and vascular endothelial cells and are also found in rodents and human infected tissues (Dalli et al. 2013a, 2015). Recently, the total synthesis of RvT1, RvT2, and its 13R-epimer RvT2, and RvT4 were successfully achieved (Rodriguez and Spur 2020a, b). Therefore, it is expected that there will be many physiological and pharmacological research on RvTs in the future. 


\section{Maresins}

Maresins (MaRs) are biosynthesized from DHA by macrophages through the action of 12-LOX, which catalyzes the oxygenation of DHA to 14-hydroperoxidocosahexaenoic acid (14-HpDHA) (Rodriguez and Spur 2020a). This is followed by reduction to $13 \mathrm{~S}, 14 \mathrm{~S}$-epoxy-maresin, which is further modified in human macrophages to produce MaR1 (Deng et al. 2014) and conversion of 13S, $14 \mathrm{~S}$-epoxy-maresin by soluble epoxide hydrolase to produce MaR2 (Deng et al. 2014). Maresins, like the many other SPM members mentioned, have anti-inflammatory, protective and healing-promoting properties. In a study using a murine model of respiratory distress syndrome, and initial in vivo production of MaR1was detected during platelet-neutrophil interactions, and its levels increased significantly within 2 hours and peaked at 24 hours (Dalli et al. 2013c). Measurement of 17-HDHA in tissue is used as a marker for the level of activation of the MaR production pathway (Wang et al. 2015). Maresinlike lipid mediators MaR-L1 and MaR-L2 are produced by white blood cells and platelets and rescue the reparative function of macrophages damaged by diabetes (Hong et al. 2014). Total synthesis of MaRs has not yet been reported.

\section{Protectins (PDs)}

Protectin D1 (PD1), also known as neuroprotectin D1 (NPD1), is derived from DHA. DHA is a component of fish oil and the most important omega-3 PUFA. Like other members of PUFA metabolites specialized pro-resolving mediators class, PD1 exerts potent anti-inflammatory and anti-apoptotic/neuroprotective biological activities (Hong et al. 2003; Bazan 2007). PD1 accumulates in the ipsilateral hemisphere of the brain after focal ischemia and has been shown to take part in wound healing and neuroprotection. 15-LOX can acts $17 \mathrm{~S}-\mathrm{HpDHA}$ to produce the isomers of PD1, 10S, 17S-diHDHA (PDx), which also have pro-resolving activity. PD1 production peaks at 12 hours in a zymosan A-induced rat peritonitis model (Bannenberg et al. 2005).

Other PDs with similar activity include PDX; 20-hydroxy-PD1; and 10-epi-PD1 (Shinohara et al. 2012; Balas and Durand 2016). The activity of 17-epi-PD1, a PD1-like metabolite, has not been reported. It should be noted that Neuroprotectin A and B, the bicyclohexapeptides, are structurally and mechanically different from PDs (Kobayashi et al. 2001). The total synthesis of PDX and PD1 methyl ester epimer was successful (Dayaker et al. 2014; Sanceau et al. 2019).

\section{SPMs receptors}

Herein, we briefly describe each known SPMs receptors (Fig. 2). Previous studies have demonstrated that pro-resolving activities of SPMs occur through activation of one or more G protein-coupled receptors (GPCRs), suitable receptors for several types of SPMs have not yet been identified. Four GPCRs have been reported as receptors for RvD1 and RvE1; however, it has not been determined whether other Rvs and PDs such as RvE2, RvE4, RvD2, RvD3, PDs, and MaRs act on these GPCRs (Arita et al. 2005, 2007; Krishnamoorthy et al. 2010). For recent and specific physiological actions of these receptors and research data in KO mice, we would like to refer to other reviews and references there (Park et al. 2020; Im 2012).

\section{Chemerin receptor 1}

Chemerin receptor 1 (chemerin1, ChemR23, or ERV1) is expressed on a wide range of immune cells, including monocytes, macrophages, natural killer cells, bone marrow cells, and dendritic cells. Besides, ERV1 has been identified in adipocytes and endothelial cells (Luangsay et al. 2009). ERV1 was initially classified as an orphan GPCR with homology to the formyl peptide receptor (Gantz et al. 1996) and the anaphylatoxin C3a and C5a receptors (Samson et al. 1998) until recently when it was discovered to be a receptor for the chemotactic protein chemerin (Meder et al. 2003).

In addition to chemerin, RvE1 was identified as a second endogenous agonist through a screening program against the GPCR panel (Arita et al. 2007). ERV1 (chemokine like receptor 1, also known as CMKLR1) is a receptor for RvE1, which has been shown to bind more strongly than chemerin (a peptide ligand) (Arita et al. 2005; Wittamer et al. 2004). ERV1 overexpressing mice showed a large increase in phagocytosis upon decreased neutrophil inhibition and decreased neutrophil infiltration (Herrera et al. 2015). Also, RvE2 is a partial agonist compared to RvE1 in CHO-chemerin1 $\beta$-arrestin recruitment (Isobe et al. 2012a). However, since there is no additional information on this ligand, further investigation of potential ligand-receptor pairs is required.

\section{$\mathrm{N}$-formyl peptide receptor 2/LX A4 receptor (FPR2/ ALX)}

Originally FPR2 was classified as an FPR receptor due to its activation by the low-affinity endogenous agonist $\mathrm{N}$-formyl methionyl peptide (fMLP) (Ye et al. 1992). The receptor was reclassified as FPR2/ALX, as LXA4 exhibited the highest affinity of all FPR2/ALX endogenous agonists through screening of various receptor ligands using radiolabelled $\left[{ }^{3} \mathrm{H}\right]-\mathrm{LXA} 4$ and subsequent GTPase activity (Fiore et al. 


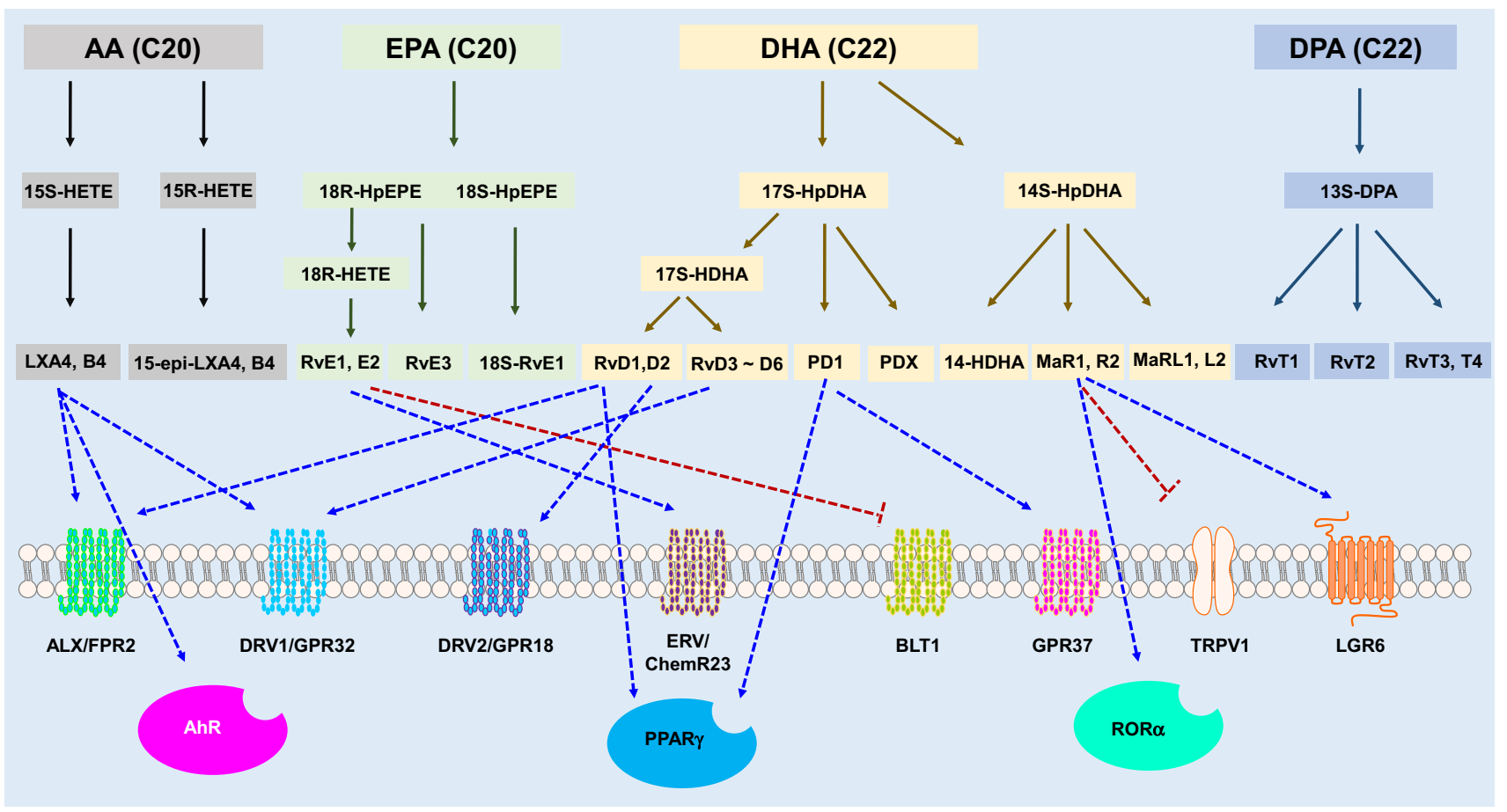

Fig. 2 SPMS and their receptors. Blue dotted lines mean activation of receptors, and red dotted lines inhibition of receptors

1994; Brink et al. 2003). Binding of LXA4 leads to the stimulation of monocyte chemotaxis, macrophage differentiation, and efferocytosis (Maderna et al. 2010; Maddox and Serhan 1996). LXA4 also reduces the adaptive immune response by reducing memory $\mathrm{B}$ cell antibody production and proliferation (Ramon et al. 2014).

Endogenous and exogenous lipids, peptides, and proteins have been shown to bind and activate FPR2/ALX to produce inflammatory and anti-inflammatory effects (Takano et al. 1997; Cooray et al. 2013). Both the LXs and Rvs families, including LXA4, AT-LXA4 (15-epi-LXA4), RvD1, ATRvD1 (17-epi-RvD1), and Annexin A1 (ANXA1) activate receptors with high potency. On the other hand, endogenous antagonists, including serum amyloid A (SAA) and cathelicidin (LL-37) have been identified (Bozinovski et al. 2012; Wan et al. 2011).

\section{GPR18}

GPR18 was discovered as a receptor for RvD2 through GPCR- $\beta$-arrestin-based screening (Chiang et al. 2015), and the receptor was referred to as DRV2/GPR18 (Chiang et al. 2017, 2019a). Besides, several other ligands activate DRV2/GPR18. These include endogenous ligands such as $\mathrm{N}$-arachidonylglycine (NAGly), anandamide, a metabolite of the endocannabinoid anandamide, synthetic ligands such as abnormal-cannabidiol (Abn-CBD), and O-1918, a partial agonist, which can be used as a pharmacological tool to inhibit DRV2/GPR18 signalling (Offertaler et al. 2003; Kohno et al. 2006). GPR18 is abundantly expressed in PMNs, monocytes and macrophages (Wang et al. 2014). In addition to the resolution of inflammation, while GPR18 has low structural similarity to the cannabinoid receptors CB1, CB2, and GPR55, it responds to endogenous and synthetic cannabinoid ligands including n-arachidonoyl ethanolamine (AEA), 2-arachidonoyl glycerol (2-AG), $\Delta$ 9-tetrahydrocannabinol $(\Delta 9-\mathrm{THC})$, and, arachidonoylcyclopropylamide (ACPA) (McHugh, 2012). Also interestingly, GPR18 is structurally very similar to EBV-induced receptor 2 (EBI2), whose expression is increased more than 20 times in Epstein-Barr virus (EBV) infected cells, and is a GPCR receptor clustered together in the 13q32 (Rosenkilde et al., 2006).

\section{GPR32}

GPR32 is primarily expressed in human PMN, monocytes, adipose tissue and vascular endothelial cells (Sansbury and Spite 2016). RvD1 was identified as a potential agonist due to the activation of GPR32, where $\left[{ }^{3} \mathrm{H}\right]-\mathrm{RvD} 1$ binds to human leukocytes and significantly lowers TNF$\alpha$-stimulated NF- $\kappa \mathrm{B}$ signalling in GPR32 overexpressing cells (Krishnamoorthy et al. 2010). Although RvD1 has a higher affinity for GPR32 than FPR2/ALX, its interaction with GPR32 has not been extensively studied (Norling et al. 2012). This could be since GPR 32 exists as a pseudogene 
in rodents, which makes animal testing in principle inappropriate. Treatment of inflammatory macrophages expressing GPR32 with RvD1 enhanced the pro-resolving phenotype to increase phagocytosis and decrease the secretion of inflammatory cytokines (Schmid et al. 2016). Also, GPR32 was also involved when during the inhibition of the EMT phenomenon of lung cancer cell lines by RvD1 (Lee et al. 2013). Additionally, RvD3, AT-RvD3, and RvD5 have all been shown to activate GPR32 in a recombinant system of $\beta$-arrestin recruitment (Dalli et al. 2013b; Chiang et al. 2012). These facts suggest the potential redundancy of ligands acting on GPCRs.

\section{GPR37}

GPR37 or Parkin-related endothelin-like receptor (Pael-R) was originally discovered through genomic library screening to find new neuropeptide receptors (Marazziti et al. 1997). The GPR37 receptor is primarily expressed in the brain and is associated with neurological disorders such as Parkin's disease and autism (Lopes et al. 2015). Mutations within GPR37 affect various autism spectrum disorders, regulation of dopamine reuptake and oligodendrocyte differentiation (Fujita-Jimbo et al. 2012; Marazziti et al. 2007; Yang et al. 2016). PD1 is considered as a ligand for GPR37 because it induced a significant increase in intracellular calcium in HEK293 cells overexpressing GPR37 and murine peritoneal-derived macrophages (Bang et al. 2018). Based on the fact that Gpr37-/- mice exhibited increased apoptosis and infarct size, it has recently been suggested that GPR37 is also involved in cell damage protection and inflammation after ischemic stroke (McCrary et al., 2019). However, due to its clear role in the central nervous system (CNS), the development of a therapeutic agent targeting GPR37 requires a balance between the effect on the central nervous system and therapeutic benefits.

\section{Leukotriene BLT1}

BLT1 has also been shown to be a receptor for RvE1 although its clone, high-affinity leukotriene B4 (LTB4) is a potent lipid inflammatory chemoattractant, inducing $\mathrm{T}$ helper cell chemotaxis and early effector T cell recruitment through BLT1 (Yokomizo et al. 1997; Arita et al. 2007). BLT1 shares 21\% sequence identity with chemerin1; while this value is relatively low, selective BLT1 antagonist U-75,302 has been demonstrated to replace the binding of $\left[{ }^{3} \mathrm{H}\right]-\mathrm{RvE} 1$ to the human PMN membrane (Arita et al. 2007). Besides, although RvE1 is 100 times less potent than LTB4, it inhibited adenylate cyclase activity and induced intracellular calcium mobilization in HEK293 cells overexpressing BLT1. These data indicate the role of RvE1 in reducing BLT1-induced inflammation by RvE1 acting as a partial agonist that competes with
LTB4-mediated NF- $\mathrm{KB}$ activation and calcium mobilization (Arita et al. 2007).

Activation of BLT1 by RvE1 also serves as a feedback mechanism for other SPMs, including increased production of LXA4 in the FPR2/ALX-mediated resolution of allergic pulmonary inflammation (Haworth et al. 2008).

RvE2 was identified as an additional BLT1 agonist, and the $\beta$-arrestin assay showed that RvE2 blocked LTB4-mediated $\beta$-arrestin signalling with similar efficacy to RvE1, indicating direct competition with LTB4 (Oh et al. 2012). Various proresolving roles of RvE2 have been proposed, including regulation of PMN infiltration and IL-10 production (Oh et al. 2012). However, while RvE1 promotes NADPH oxidase-mediated ROS production through the BLT1, RvE2 and RvE3 do not exhibit this effect (Unno et al. 2018).

\section{Activation of other receptors by SPMs}

A few studies have reported the possibility of other GPCR involvement. Among them, GPR101 mediates the pro-resolving effects of RvD5n-3 DPA in arthritis and infection (Flak et al. 2020). Besides, SPMs have been reported to activate non-GPCRs receptors, such as nuclear receptors.

In a dose-dependent manner, PD1 enhances PPAR $\gamma$ transcriptional activation reporter activity in human neuronglia (HNG) cells co-transfected with hPPAR $\gamma$-GAL4 and MH100-tk-Luc (Zhao et al. 2011). This suggests that PD1 is capable of enhancing the peroxisome proliferator-activated receptor gamma (PPAR $\gamma$ ) (Fig. 2). The transcriptional activity of PPAR $\gamma$ was significantly increased after treatment with $100 \mathrm{nM}$ PD1. RvD1 was also assumed to be a ligand

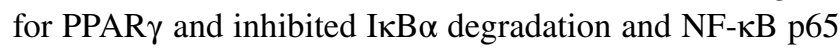
nuclear translocation in an LPS-induced lung injury model, which was partially reversed by the PPAR $\gamma$ inhibitor GW9662 (Fig. 2) (Liao et al. 2012). Recently, it has been reported that LXA4 binds to the nuclear aryl hydrocarbon receptor (AhR) (Fig. 2) (Asha et al. 2020).

A GPCR that acts directly on MaR1 has not yet been identified. However, MaR1 blocks TRPV1-mediated currents in neurons, acts as a ligand for the retinoid-associated orphan receptor $\alpha(\mathrm{ROR} \alpha)$, and inhibits TLR4 signalling (Fig. 2) (Park 2015), Chiang et al. found that MaR1 can activate LGR6, a member of the glycoprotein hormone receptor subfamily of rhodopsin-like GPCRs (Chiang et al. 2019b), which initiates cAMP, impedance changes, and stimulate an innate immune response against PMNs, monocytes and macrophages (Chiang et al. 2019b). 


\section{Role of SPMs and Their Receptors in Virus Infections}

Because viruses are obligate intracellular parasites, viruses must enter target cells and multiply using host cell machinery to produce progeny viruses (Ryu 2017). The various stages involved in viral growth that occur inside cells are called the viral life cycle. The viral life cycle can be divided into three stages: entry, genome replication, and exit. Entry can be subdivided into attachment, penetration and uncoating, and exit can be subdivided into virion assembly and release. Genome replication differs by virus type. Many studies are showing that SPMs regulate the inflammatory response caused by viral infections, but studies on the effects of SPMs on the viral life cycle have been difficult to find. There have a few reports recently. For example, among SPMs, LXA4 modulates Kaposi's Sarcoma-Associated Herpesvirus (KSHV) life cycle through chromatin modulation and hedgehog signalling to destabilize the latency of herpes virus and decreases the expression of programmed death-ligand 1 (PD-L1) in Kaposi's Sarcoma, thereby reducing immune evasion (Fig. 3) (Asha et al. 2020). On the other hand, there are not a few reports that the receptors mentioned above for SPMs act as receptors in virus infection (see below). So, in this section, we will discuss the effect of SPMs on the virus and the viral infection-induced inflammation and mention how the receptors of SPMs affect the life cycle of the virus (Fig. 3).

\section{Influenza}

Influenza viruses are a well-studied model for understanding the role of inflammation resolution mediators and the mechanism of viral infection. This is because different viruses elicit different host immune responses and outcomes. From studies comparing more virulent influenza virus strains to less virulent strains, it has been reported that pro-resolving mediators have an inverse correlation with the biological activity of the virus (Cilloniz et al. 2010). The more toxic strains of influenza induced reduction of LXs, which increased the spread of the virus. LXB4 recently improved $\mathrm{IgG}$ production in $\mathrm{B}$ cells from donors vaccinated against influenza virus, suggesting potential as a novel adjuvant. (Kim et al. 2018).

Annexin is the most abundant host cell protein in the virion, and annexin A1 (ANXA1) contributes to influenzainduced toxicity (Tcherniuk et al. 2016). That is, during virus entry into the host cell, viral hemagglutinin (HA) not only binds sialic acid but also ANXA1 binds to FPR2, resulting in activation of ERK2 and increased viral replication (Tcherniuk et al. 2016). RvD1 and LXA4 also activate FPR2. It is still unknown whether RvD1 and LXA4 compete with viral annexin at the receptors site leads to the prevention of viral

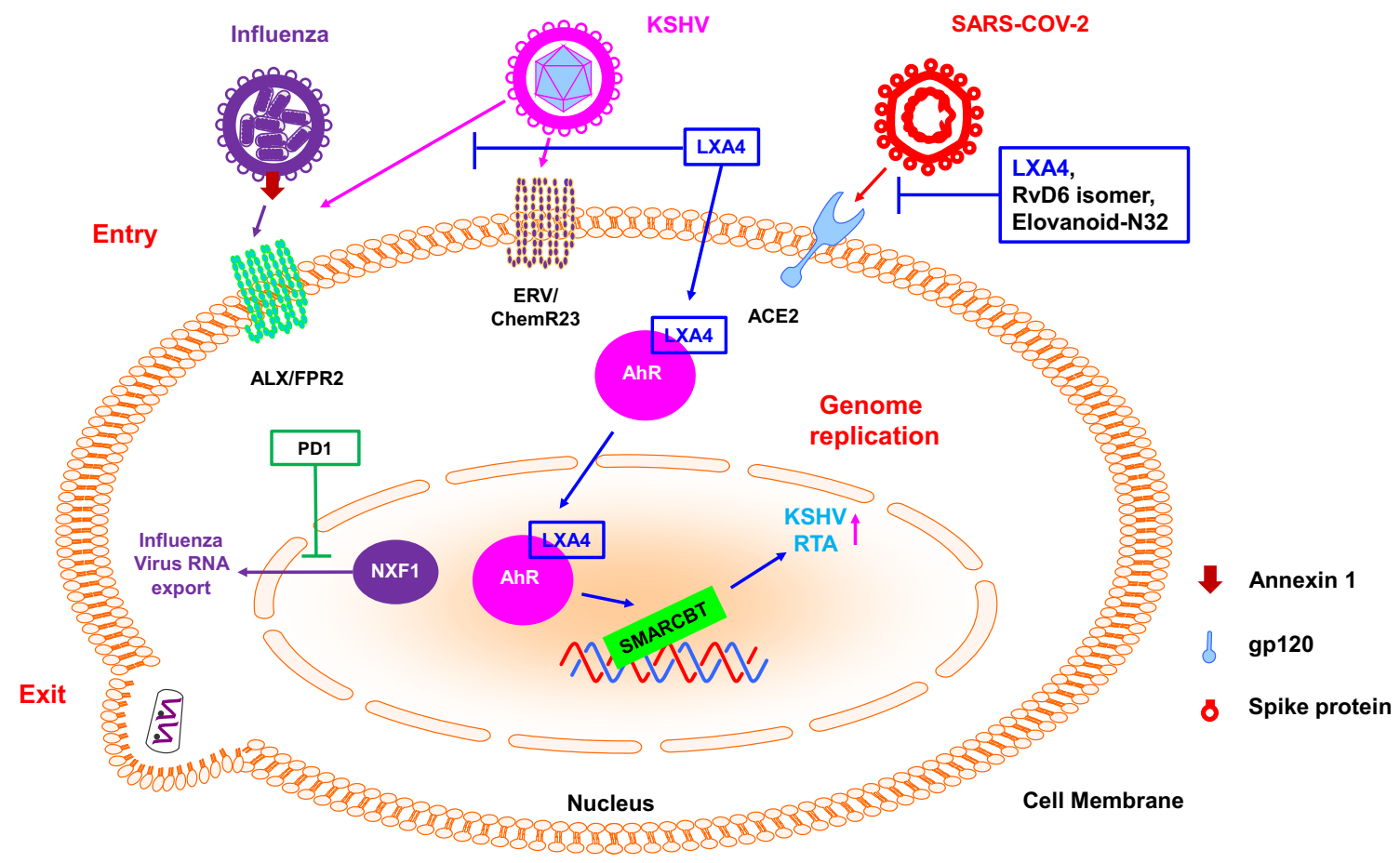

Fig. 3 Effects of SPMS on the virus life cycle. Please refer to the text for details. RTA: replication and transcription activator, KSHV: Kaposi's sarcoma-associated herpesvirus 
infection or the promotion of viral replication. However, it is reported that AT-RvD1 reduces inflammation caused by the viral infection. (Wang et al. 2017). Increased SAA in recurrent acute exacerbations of COPD caused by bacterial and virus coinfection acts as a functional agonist of FPR2/ ALX, antagonizing the protective action of FPR2/ALX by AT-RvD1, promoting chemotaxis of neutrophils and prolonging survival (Wang et al. 2018).

There are no reports of direct research on whether RvD1, the same family as AT-RvD1, inhibits the influenza virus. However, it promotes inflammation and removal of bacteria caused by a bacterial infection. For example, RvD1 relieves lung inflammation and promotes the elimination of untypeable Haemophilus influenza (Croasdell et al. 2016). ChemR23, a receptor for RvE1, relieves lung inflammation and enhances antiviral immunity in a mouse model of acute viral pneumonia (Bondue et al., 2011). Therefore, it would be fascinating to study whether RvE1 is effective in pneumonia caused by the influenza virus.

PD1 has pivotal and multiple roles in regulating viral pathogenicity. Influenza strains, such as the lethal H5N1, down-regulate PD1 (Tam et al. 2013). There is an inverse correlation between the level of PD1 and the level of pathogenicity of various virus isolates. In addition to the host's inflammatory response, PD1 has a direct antiviral action against influenza. Both PD1 and its isomer PDX (LOXmediated double oxygenation) limit viral replication by interfering with the viral RNA nuclear transport mechanism
(Fig. 3) (Imai 2015; Morita et al. 2013; Baillie and Digard 2013). Treatment of infected mice with PD1 improves survival, even if administered 48 hours after the onset of infection when the current antiviral therapy is no longer significantly effective (Fig. 4) (Morita et al. 2013; Ng et al. 2010).

\section{Herpes simplex virus}

Herpesviruses 1 and 2 (HSV-1 and HSV-2), with the taxonomic names human alphaherpesvirus 1 and human alphaherpesvirus 2, are the most common causes of human viral infections among the members of the human Herpesviridae family (Chayavichitsilp et al. 2009). Herpes simplex virus (HSV) ocular infection represents another example in which local control of the virus stems from a robust inflammatory response with long-term consequences of chronic inflammation, including the possibility of final blindness due to interstitial keratitis that persists even after the viral infection has been cleared.

In animals with HSV, topical administration of RvE1 reduced the influx of $\mathrm{CD}^{+}{ }^{+} \mathrm{T}$ cells (both $\mathrm{TH} 1$ cells and TH17 cells) and neutrophils, decreased production of inflammatory cytokines including IFN $\gamma$ and IL-6, and increased levels of the anti-inflammatory cytokine IL-10 (Fig. 4) (Rajasagi et al. 2011). Overall, RvE1 significantly reduced stromal keratitis. Similar results were demonstrated with PD1 (Fig. 4) (Rajasagi et al. 2013). Besides, AT-RvD1 treatment significantly reduced the degree of corneal angiogenesis and the

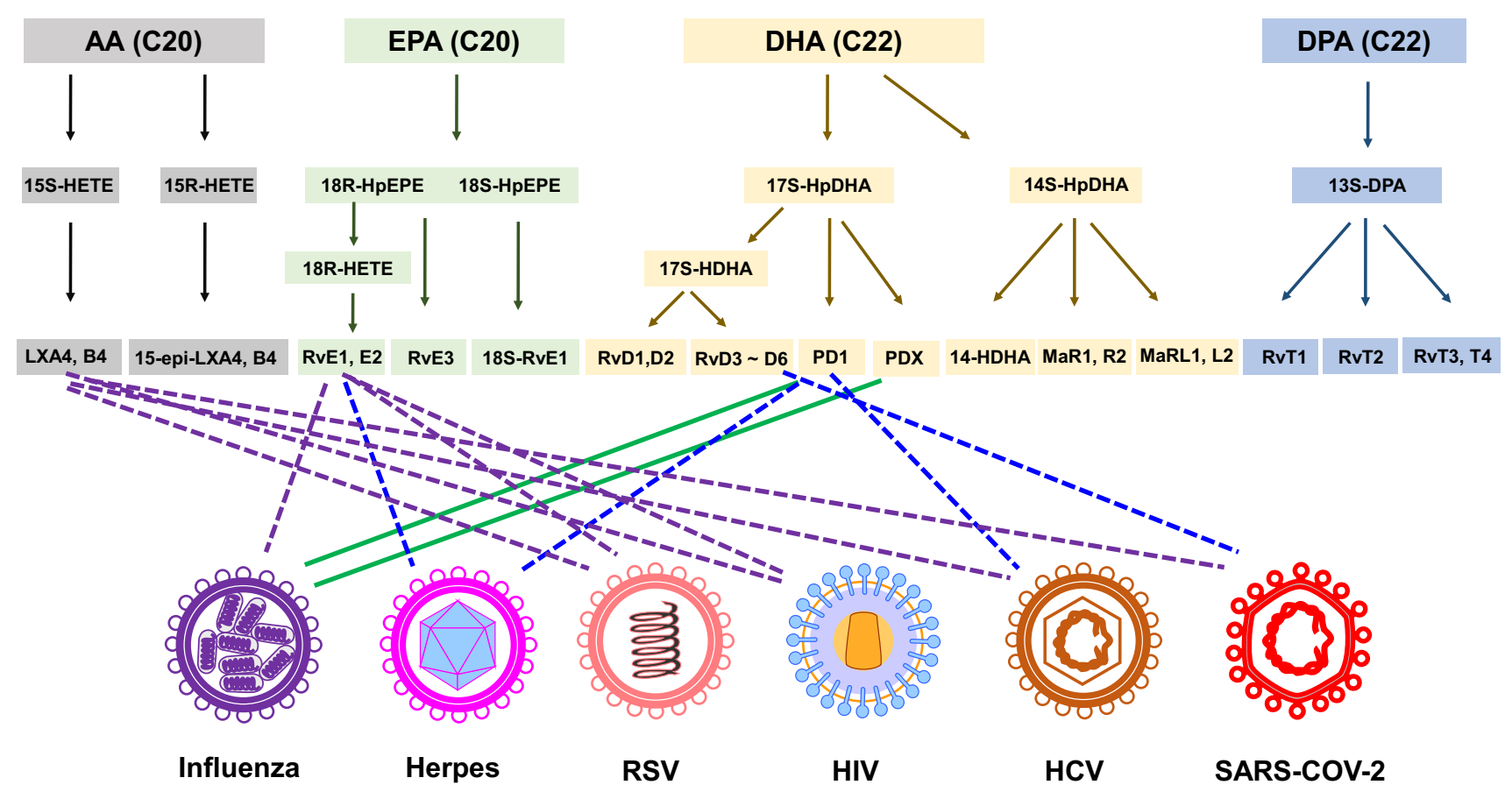

Fig. 4 Effects of SPMS on the viruses and viral infection-induced inflammation. Green lines mean direct antiviral effects. Blue dotted lines mean indirect effects on virus and purple dotted lines possible effects (not proved) 
severity of stromal keratitis lesions, and AT-RvD1 treated mice had fewer Th1 and Th17 cells in the infected cornea, as well as the reduced number of inflammatory cells, including neutrophils (Rajasagi et al. 2017).

\section{Respiratory syncytial virus, human immunodeficiency virus, and hepatitis $C$ virus}

Respiratory syncytial virus (RSV), also known as human respiratory cell fusion virus (HRSV) and human orthopneumovirus, is a virus that causes respiratory infections in which infected mucosal cells fuse to form a syncytium (Schweitzer and Justice 2020). It is the leading cause of lower respiratory tract infections and hospital visits in infancy and childhood (Read and Bosco 2020). RSV infection results in bronchiolitis, which is classically caused by activated macrophages and eventually resolved by alternatively activated macrophages (Shirey et al. 2010). The promotion of these two alternative macrophage fates appears to be related to RSV-induced COX-2 and LXA4 and RvE1-mediated protective measures (Fig. 4) (Richardson et al. 2005; Shirey et al. 2014). Also, although it does not directly act on the virus, RvD1 inhibits inflammatory signal transduction by polyinosinic-polycytidylic acid, an analogue of RNAs derived from respiratory viruses such as RSV, and the action of RvD1 is mediated by FPR2/ALX and GPR32 (Hsiao et al. 2014). These reports suggest the critical role of SPMs and lipid mediator class shift in the host's response to RSV in the initial control and final infection clearance.

Human immunodeficiency virus (HIV) is a lentivirus (a subgroup of retroviruses) and are classified into two based on the genetic characteristics and viral antigen, HIV-1 and HIV-2. HIV infection may progress to acquired immunodeficiency syndrome (AIDS), a progressive failure of the immune system. Over time, AIDS causes life-threatening opportunistic infections and a condition in which cancer thrives (Douek et al. 2009; Powell et al. 2016).

When co-cultured with HIV-1 infected mononuclear cells and human glial cells (astrocytoma, glial and primary human astrocyte), tumour necrosis factor alpha (TNF- $\alpha$ ) and interleukin- $1 \beta$ are produced, and large amounts of LTB4, LTD4, LXA4, and PAF, were also found in media from this co-culture (Fig. 4) (Genis et al. 1992). So far, this is the only in vitro study to prove, that LXs are produced in direct response to viral infection. However, the role of LXs in this infection model has not been investigated. Synthetic peptides derived from human immunodeficiency virus type 1 gp120 activate the 7-transmembrane GPCR FPR2/ALX, down-regulating the expression and function of chemokine receptors CCR5 and CXCR4 in monocytes (Deng et al. 1999).

FPR2/ALX acts as an efficient core receptor for the primary isolate of HIV (Shimizu et al. 2008). Viral entries through the alternative core receptors (CoR) CCR3 and
FPR2/ALX depend on the HIV type 1 subtype. Viruses pseudotyped with subtype A and C Env proteins use the recently described alternative CoR FPR2 more efficiently than CCR3 (Nedellec et al. 2009). ChemR23 also acts as a CoR for HIV. At this time, HIV-1 and HIV-2 appear to use the N-terminus and the second extracellular loop of ChemR23 during infection (Martensson et al. 2006). As mentioned above, research is needed to determine the role of SPMs that act as ligands for FPR2 and ChemR23 in HIV infection.

Hepatitis $\mathrm{C}$ virus (HCV) is a positive-sense singlestranded RNA virus of the family Flaviviridae with a small (55-65 nm size) envelope (Lee et al. 2017). The HCV is the cause of hepatitis $\mathrm{C}$ and some cancers such as liver cancer (hepatocellular carcinoma, abbreviated HCC) and lymphoma in humans (Ferri et al. 2015; Rusyn and Lemon 2014). To date, there appears to be no report on the effectiveness of SPMs against HCV. However, HCV peptide (C5A), an amphiphilic $\alpha$-helix peptide of HCV, is an activator of the $\mathrm{N}$-formyl peptide receptor in human phagocytes (Lin et al. 2011). This suggests the possibility of interaction between RvD1 and LXA4, FPR families, and HCV. Vitamin D metabolites inhibit HCV and upregulate GPR37 gene expression, which induces cellular autophagy (Gutierrez et al. 2014). PD1 was recently proposed as a new ligand for GPR37, and some studies suggest a possible relationship between PD1 and HCV (Fig. 4). SAA also has antiviral effects against $\mathrm{HCV}$, however, it induces chronic inflammation through FPR2/ALX, causing liver damage (Abouelasrar Salama et al. 2019). Although research has not been conducted yet, RvD1 and LXA4, which inhibit the action of SAA, are likely to suppress liver damage caused by SAA during $\mathrm{HCV}$ infection.

\section{SARS-CoV-2}

Severe acute respiratory syndrome Coronavirus 2 (SARS$\mathrm{CoV}-2$ ) refers to a coronavirus strain that causes 2019 coronavirus disease (COVID-19), a respiratory disease that is the cause of the COVID-19 pandemic (Coronaviridae Study Group of the International Committee on Taxonomy of, 2020). SARS-CoV-2 is an RNA virus that infects the lungs and causes deaths through complications such as cytokine storms (Goldin et al. 2020).

The anti-inflammatory action of mesenchymal stem cells is well known, and it is believed that these mesenchymal stem cells exhibit anti-inflammatory action through PGE2 and LXA4. These lipids mediators alleviate the SARSCoV-2 cytokine storm, while arachidonic acid, dihomogamma-linolenic acid, and gamma-linolenic acid inactivate enveloped viruses (Das 2020). Obesity is a risk factor for SARS-CoV-2 infection, and a BMI of $30 \mathrm{~kg} / \mathrm{m}^{2}$ increases the risk of infection by $61 \%$ (Bello-Chavolla et al. 2020). 
This is likely due to a deficiency of SPMs in obese patients, and this deficiency promotes adverse reactions during SARS-CoV-2 infection (Pal et al. 2020). LXA4, ElovanoidN32 or RvD6 isomers reduced expression of angiotensinconverting enzyme 2 (ACE2), but NDP1 did not reduce it. These lipids mediators also counteract the binding of the receptor-binding domain (RBD) of SARS-CoV-2 spike (S) protein to the injured cornea (Figs. 3 and 4) (Pham et al. 2020). Elovanoid-N32 or RvD6 isomers also attenuated the expression of cytokines involved in a cytokine storm and hyperinflammation. Based on previous study results that have demonstrated SPMs as potential therapeutic targets for SARS-CoV-2 infection, studies and review on the use of fish oil, an SPMs precursor, as an adjuvant are in progress. (Torrinhas et al. 2020; Rogero et al. 2020). SPMs and soluble epoxide hydrolase inhibitors are currently in clinical trials for other inflammatory diseases and can be quickly converted and used for SARS-CoV-2 management through the removal of cellular debris and inhibition of inflammatory cytokines (Panigrahy et al. 2020).

\section{Conclusions}

Recently, a new group of molecules, named SPMs that resolve inflammation were elucidated. Further, in efforts to investigate and demonstrate their mechanism of action, their receptors are slowly being discovered. As an additional milestone, SPMs were detected in several biological samples. However, the investigation of the pharmacological principle based on GPCR for SPMs under various physiological and pathological conditions is insufficient (Psychogios et al. 2011; Lukiw et al. 2005). Further research is needed on specific molecular targets of omega- 3 fatty acids such as RvE2, RvD2, PDs, and MaRs. The interaction between the host immune system and infectious viral attacks represents new opportunities for the utilization of SPMs. The use of SPMs is likely to help regulate abnormal viral-mediated inflammation and prevent complications such as SARS-CoV-2 cytokine storm. Besides, SPMs play parts in restoring tissue homeostasis, including wound healing. Therefore, they are very likely to have therapeutic effects against the sequelae of SARS-CoV-2 infection. Both inflammation and resolution of inflammation are vital processes of the immune system. Therefore, a balance between the need for a sufficient immune response to clear the infection and the rapid decline of immune response to prevent host damage presents a novel opportunity for therapeutic exploitation of the SPMs.

Further research is needed to identify opportunities to optimize this balance in human viral infectivity. Among them, it will be exciting to study how the receptors of SPMs, which act as coreceptors during virus infection, play a role in virus infection and virus-induced inflammation. Finally, although not mentioned in this review, the author would like to emphasize that SPMs are effective in treating bacterial infections as well.

In nutshell, SPMs shows excellent potential as novel therapeutic options for severe inflammation and tissue damage caused by viral infections, including SARS-CoV-2 infection.

Acknowledgements This research was supported by National Research Foundation of Korea (NRF 2018R1E1A2A02057995, NRF-2018R1A5A 2023127, NRF-2020R1A2C3004973, NRF-2020M3E5E2038356).

\section{Compliance with ethical standards}

Conflict of interest Nothing to declare.

\section{References}

Abouelasrar Salama S, Lavie M, De Buck M, Van Damme J, Struyf S (2019) Cytokines and serum amyloid A in the pathogenesis of hepatitis C virus infection. Cytokine Growth Factor Rev 50:2942. https://doi.org/10.1016/j.cytogfr.2019.10.006

Arita M, Bianchini F, Aliberti J, Sher A, Chiang N, Hong S, Yang R, Petasis NA, Serhan CN (2005) Stereochemical assignment, antiinflammatory properties, and receptor for the omega-3 lipid mediator resolvin E1. J Exp Med 201:713-722. https://doi. org/10.1084/jem.20042031

Arita M, Ohira T, Sun YP, Elangovan S, Chiang N, Serhan CN (2007) Resolvin E1 selectively interacts with leukotriene B4 receptor BLT1 and ChemR23 to regulate inflammation. J Immunol 178:3912-3917. https://doi.org/10.1084/jem.20042031

Asha K, Balfe N, Sharma-Walia N (2020) Concurrent Control of the Kaposi's Sarcoma-Associated Herpesvirus Life Cycle through Chromatin Modulation and Host Hedgehog Signaling: a New Prospect for the Therapeutic Potential of Lipoxin A4. J Virol 94:e02177-e02119. https://doi.org/10.1128/JVI.02177-19

Baillie JK, Digard P (2013) Influenza-time to target the host? N Engl J Med 369:191-193. https://doi.org/10.1056/NEJMcibr1304414

Balas L, Durand T (2016) Dihydroxylated E,E,Z-docosatrienes. An overview of their synthesis and biological significance. Prog Lipid Res 61:1-18. https://doi.org/10.1016/j.plipres.2015.10.002

Bang S, Xie YK, Zhang ZJ, Wang Z, Xu ZZ, Ji RR (2018) GPR37 regulates macrophage phagocytosis and resolution of inflammatory pain. J Clin Invest 128:3568-3582. https://doi.org/10.1172/ JCI99888

Bannenberg GL, Chiang N, Ariel A, Arita M, Tjonahen E, Gotlinger KH, Hong S, Serhan CN (2005) Molecular circuits of resolution: formation and actions of resolvins and protectins. J Immunol 174:4345-4355. https://doi.org/10.4049/jimmunol.174.7.4345

Bazan NG (2007) Omega-3 fatty acids, pro-inflammatory signaling and neuroprotection. Curr Opin Clin Nutr Metab Care 10:136-141. https://doi.org/10.1097/MCO.0b013e32802b7030

Bello-Chavolla OY, Bahena-Lopez JP, Antonio-Villa NE, VargasVazquez A, Gonzalez-Diaz A, Marquez-Salinas A, FerminMartinez CA, Naveja JJ, Aguilar-Salinas CA (2020) Predicting mortality due to SARS-CoV-2: a mechanistic score relating obesity and diabetes to COVID-19 Outcomes in Mexico. J Clin Endocrinol Metab. https://doi.org/10.1210/clinem/dgaa346

Bondue B, Vosters O, De Nadai P, Glineur S, De Henau O, Luangsay S, Van Gool F, Communi D, De Vuyst P, Desmecht D, Parmentier M (2011a) ChemR23 dampens lung inflammation and enhances anti-viral immunity in a mouse model of acute viral 
pneumonia. PLoS Pathog 7:e1002358. https://doi.org/10.1371/ journal.ppat.1002358

Bozinovski S, Uddin M, Vlahos R, Thompson M, Mcqualter JL, Merritt AS, Wark PA, Hutchinson A, Irving LB, Levy BD, Anderson GP (2012) Serum amyloid A opposes lipoxin A(4) to mediate glucocorticoid refractory lung inflammation in chronic obstructive pulmonary disease. Proc Natl Acad Sci USA 109:935-940. https://doi.org/10.1073/pnas.1109382109

Brink C, Dahlen SE, Drazen J, Evans JF, Hay DW, Nicosia S, Serhan CN, Shimizu T, Yokomizo T (2003) International Union of Pharmacology XXXVII. Nomenclature for leukotriene and lipoxin receptors. Pharmacol Rev 55:195-227. https://doi.org/10.1124/ pr.55.1.8

Chayavichitsilp P, Buckwalter JV, Krakowski AC, Friedlander SF (2009) Herpes simplex. Pediatr Rev 30:119-129. https://doi. org/10.1542/pir.30-4-119. quiz 130.

Chiang N, Arita M, Serhan CN (2005) Anti-inflammatory circuitry: lipoxin, aspirin-triggered lipoxins and their receptor ALX. Prostaglandins Leukot Essent Fatty Acids 73:163-177. https://doi. org/10.1016/j.plefa.2005.05.003

Chiang N, Barnaeva E, Hu X, Marugan J, Southall N, Ferrer M, Serhan CN (2019) Identification of chemotype agonists for human resolvin D1 receptor DRV1 with pro-resolving functions. Cell Chem Biol 26:244-254 e4. https://doi.org/10.1016/j.chemb iol.2018.10.023

Chiang N, Dalli J, Colas RA, Serhan CN (2015) Identification of resolvin D2 receptor mediating resolution of infections and organ protection. J Exp Med 212:1203-1217. https://doi.org/10.1084/ jem. 20150225

Chiang N, De La Rosa X, Libreros S, Serhan CN (2017) Novel Resolvin D2 receptor axis in infectious inflammation. J Immunol 198:1842-1851. https://doi.org/10.4049/jimmunol.1601650

Chiang N, Fredman G, Backhed F, Oh SF, Vickery T, Schmidt BA, Serhan CN (2012) Infection regulates pro-resolving mediators that lower antibiotic requirements. Nature 484:524-528. https:// doi.org/10.1038/nature11042

Chiang N, Libreros S, Norris PC, De La Rosa X, Serhan CN (2019b) Maresin 1 activates LGR6 receptor promoting phagocyte immunoresolvent functions. J Clin Invest 129:5294-5311. https://doi. org/10.1172/JCI129448

Chiang N, Serhan CN (2017) Structural elucidation and physiologic functions of specialized pro-resolving mediators and their receptors. Mol Aspects Med 58:114-129. https://doi.org/10.1016/j. mam.2017.03.005

Cilloniz C, Pantin-Jackwood MJ, Ni C, Goodman AG, Peng X, Proll SC, Carter VS, Rosenzweig ER, Szretter KJ, Katz JM, Korth MJ, Swayne DE, Tumpey TM, Katze MG (2010) Lethal dissemination of $\mathrm{H} 5 \mathrm{~N} 1$ influenza virus is associated with dysregulation of inflammation and lipoxin signaling in a mouse model of infection. J Virol 84:7613-7624. https://doi.org/10.1128/JVI.00553 $-10$

Claria J, Serhan CN (1995) Aspirin triggers previously undescribed bioactive eicosanoids by human endothelial cell-leukocyte interactions. Proc Natl Acad Sci USA 92:9475-9479. https:// doi.org/10.1073/pnas.92.21.9475

Cooray SN, Gobbetti T, Montero-Melendez T, Mcarthur S, Thompson D, Clark AJ, Flower RJ, Perretti M (2013) Ligand-specific conformational change of the G-protein-coupled receptor ALX/ FPR2 determines proresolving functional responses. Proc Natl Acad Sci USA 110:18232-18237. https://doi.org/10.1073/ pnas. 1308253110

Coronaviridae Study Group of the International Committee on Taxonomy Of, V (2020) The species Severe acute respiratory syndrome-related coronavirus: classifying 2019-nCoV and naming it SARS-CoV-2. Nat Microbiol 5:536-544. https://doi.org/10.1038/ s41564-020-0695-Z
Croasdell A, Lacy SH, Thatcher TH, Sime PJ, Phipps RP (2016) Resolvin D1 Dampens Pulmonary Inflammation and Promotes Clearance of Nontypeable Haemophilus influenzae. J Immunol 196:2742-2752. https://doi.org/10.4049/jimmunol.1502331

Dalli J, Chiang N, Serhan CN (2015) Elucidation of novel 13-series resolvins that increase with atorvastatin and clear infections. Nat Med 21:1071-1075. https://doi.org/10.1038/nm.3911

Dalli J, Colas RA, Serhan CN (2013) Novel n-3 immunoresolvents: structures and actions. Sci Rep 3:1940. https://doi.org/10.1038/ srep01940

Dalli J, Winkler JW, Colas RA, Arnardottir H, Cheng CY, Chiang N, Petasis NA, Serhan CN (2013b) Resolvin D3 and aspirintriggered resolvin D3 are potent immunoresolvents. Chem Biol 20:188-201. https://doi.org/10.1016/j.chembiol.2012.11.010

Dalli J, Zhu M, Vlasenko NA, Deng B, Haeggstrom JZ, Petasis NA, Serhan CN (2013c) The novel 13S,14S-epoxy-maresin is converted by human macrophages to maresin 1 (MaR1), inhibits leukotriene A4 hydrolase (LTA4H), and shifts macrophage phenotype. FASEB J 27:2573-2583. https://doi.org/10.1096/ fj. $13-227728$

Das UN (2020) Bioactive lipids as mediators of the beneficial action(s) of mesenchymal stem cells in COVID-19. Aging Dis 11:746-755. https://doi.org/10.14336/AD.2020.0521

Dayaker G, Durand T, Balas L (2014) A versatile and stereocontrolled total synthesis of dihydroxylated docosatrienes containing a conjugated E,E,Z-triene. Chemistry 20:2879-2887. https ://doi.org/10.1002/chem.201304526

Deng B, Wang CW, Arnardottir HH, Li Y, Cheng CY, Dalli J, Serhan CN (2014) Maresin biosynthesis and identification of maresin 2 , a new anti-inflammatory and pro-resolving mediator from human macrophages. PLoS ONE 9:e102362. https://doi. org/10.1371/journal.pone.0102362

Deng X, Ueda H, Su SB, Gong W, Dunlop NM, Gao JL, Murphy PM, Wang JM (1999) A synthetic peptide derived from human immunodeficiency virus type 1 gp120 downregulates the expression and function of chemokine receptors CCR5 and CXCR4 in monocytes by activating the 7-transmembrane G-protein-coupled receptor FPRL1/LXA4R. Blood 94:1165-1173

Douek DC, Roederer M, Koup RA (2009) Emerging concepts in the immunopathogenesis of AIDS. Annu Rev Med 60:471-484. https ://doi.org/10.1146/annurev.med.60.041807.123549

Duvall MG, Levy BD (2016) DHA- and EPA-derived resolvins, protectins, and maresins in airway inflammation. Eur J Pharmacol 785:144-155. https://doi.org/10.1016/j.ejphar.2015.11.001

Ferri C, Sebastiani M, Giuggioli D, Colaci M, Fallahi P, Piluso A, Antonelli A, Zignego AL (2015) Hepatitis C virus syndrome: a constellation of organ- and non-organ specific autoimmune disorders, B-cell non-Hodgkin's lymphoma, and cancer. World J Hepatol 7:327-343. https://doi.org/10.4254/wjh.v7.i3.327

Fiore S, Maddox JF, Perez HD, Serhan CN (1994) Identification of a human cDNA encoding a functional high affinity lipoxin A4 receptor. J Exp Med 180:253-260. https://doi.org/10.1084/ jem.180.1.253

Flak MB, Koenis DS, Sobrino A, Smith J, Pistorius K, Palmas F, Dalli J (2020) GPR101 mediates the pro-resolving actions of RvD5n-3 DPA in arthritis and infections. J Clin Invest 130:359-373. https ://doi.org/10.1172/JCI131609

Fujita-Jimbo E, Yu ZL, Li H, Yamagata T, Mori M, Momoi T, Momoi MY (2012) Mutation in Parkinson disease-associated, G-proteincoupled receptor 37 (GPR37/PaelR) is related to autism spectrum disorder. PLoS ONE 7:e51155. https://doi.org/10.1371/journ al.pone.0051155

Fullerton JN, Gilroy DW (2016) Resolution of inflammation: a new therapeutic frontier. Nat Rev Drug Discov 15:551-567. https:// doi.org/10.1038/nrd.2016.39 
Gantz I, Konda Y, Yang YK, Miller DE, Dierick HA, Yamada T (1996) Molecular cloning of a novel receptor (CMKLR1) with homology to the chemotactic factor receptors. Cytogenet Cell Genet 74:286-290. https://doi.org/10.1159/000134436

Genis P, Jett M, Bernton EW, Boyle T, Gelbard HA, Dzenko K, Keane RW, Resnick L, Mizrachi Y, Volsky DJ et al (1992) Cytokines and arachidonic metabolites produced during human immunodeficiency virus (HIV)-infected macrophage-astroglia interactions: implications for the neuropathogenesis of HIV disease. J Exp Med 176:1703-1718. https://doi.org/10.1084/jem.176.6.1703

Goldin CJ, Vazquez R, Polack FP, Alvarez-Paggi D (2020) Identifying pathophysiological bases of disease in COVID-19. Transl Med Commun 5:15. https://doi.org/10.1186/s41231-020-00067-w

Gutierrez JA, Jones KA, Flores R, Singhania A, Woelk CH, Schooley RT, Wyles DL (2014) Vitamin D metabolites inhibit hepatitis C virus and modulate cellular gene expression. J Virol Antivir Res. https://doi.org/10.4172/2324-8955.1000129

Haworth O, Cernadas M, Yang R, Serhan CN, Levy BD (2008) Resolvin E1 regulates interleukin 23, interferon-gamma and lipoxin A4 to promote the resolution of allergic airway inflammation. Nat Immunol 9:873-879. https://doi.org/10.1038/ni.1627

Headland SE, Norling LV (2015) The resolution of inflammation: principles and challenges. Semin Immunol 27:149-160. https://doi. org/10.1016/j.smim.2015.03.014

Herrera BS, Hasturk H, Kantarci A, Freire MO, Nguyen O, Kansal S, Van Dyke TE (2015) Impact of resolvin E1 on murine neutrophil phagocytosis in type 2 diabetes. Infect Immun 83:792-801. https ://doi.org/10.1128/IAI.02444-14

Hong S, Gronert K, Devchand PR, Moussignac RL, Serhan CN (2003) Novel docosatrienes and 17S-resolvins generated from docosahexaenoic acid in murine brain, human blood, and glial cells. Autacoids in anti-inflammation. J Biol Chem 278:14677-14687. https://doi.org/10.1074/jbc.M300218200

Hong S, Lu Y, Tian H, Alapure BV, Wang Q, Bunnell BA, Laborde JM (2014) Maresin-like lipid mediators are produced by leukocytes and platelets and rescue reparative function of diabetesimpaired macrophages. Chem Biol 21:1318-1329. https://doi. org/10.1016/j.chembiol.2014.06.010

Hong S, Porter TF, Lu Y, Oh SF, Pillai PS, Serhan CN (2008) Resolvin E1 metabolome in local inactivation during inflammation-resolution. J Immunol 180:3512-3519. https://doi.org/10.4049/jimmu nol.180.5.3512

Hsiao HM, Thatcher TH, Levy EP, Fulton RA, Owens KM, Phipps RP, Sime PJ (2014) Resolvin D1 attenuates polyinosinic-polycytidylic acid-induced inflammatory signaling in human airway epithelial cells via TAK1. J Immunol 193:4980-4937. https:// doi.org/10.4049/jimmunol.1400313

Im DS (2012) Omega-3 fatty acids in anti-inflammation (pro-resolution) and GPCRs. Prog Lipid Res 51:232-237. https://doi. org/10.1016/j.plipres.2012.02.003

Imai Y (2015) Role of omega-3 PUFA-derived mediators, the protectins, in influenza virus infection. Biochim Biophys Acta 1851:496-502. https://doi.org/10.1016/j.bbalip.2015.01.006

Isobe Y, Arita M, Matsueda S, Iwamoto R, Fujihara T, Nakanishi H, Taguchi R, Masuda K, Sasaki K, Urabe D, Inoue M, Arai $\mathrm{H}$ (2012a) Identification and structure determination of novel anti-inflammatory mediator resolvin E3, 17,18-dihydroxyeicosapentaenoic acid. J Biol Chem 287:10525-10534. https://doi. org/10.1074/jbc.M112.340612

Isobe Y, Kato T, Arita M (2012b) Emerging roles of eosinophils and eosinophil-derived lipid mediators in the resolution of inflammation. Front Immunol 3:270. https://doi.org/10.3389/fimmu .2012 .00270

Kim N, Lannan KL, Thatcher TH, Pollock SJ, Woeller CF, Phipps RP (2018) Lipoxin B4 enhances human memory B cell antibody production via upregulating cyclooxygenase- 2 expression.
J Immunol 201:3343-3351. https://doi.org/10.4049/jimmu nol.1700503

Kobayashi H, Shin-Ya K, Nagai K, Suzuki K, Hayakawa Y, Seto H, Yun BS, Ryoo IJ, Kim JS, Kim CJ, Yoo ID (2001) Neuroprotectins $\mathrm{A}$ and $\mathrm{B}$, bicyclohexapeptides protecting chick telencephalic neuronal cells from excitotoxicity. I. Fermentation, isolation, physico-chemical properties and biological activity. J Antibiot (Tokyo) 54:1013-1018. https://doi.org/10.7164/antib iotics.54.1013

Kohno M, Hasegawa H, Inoue A, Muraoka M, Miyazaki T, Oka K, Yasukawa M (2006) Identification of $\mathrm{N}$-arachidonylglycine as the endogenous ligand for orphan G-protein-coupled receptor GPR18. Biochem Biophys Res Commun 347:827-832. https:// doi.org/10.1016/j.bbrc.2006.06.175

Krishnamoorthy S, Recchiuti A, Chiang N, Yacoubian S, Lee CH, Yang R, Petasis NA, Serhan CN (2010) Resolvin D1 binds human phagocytes with evidence for proresolving receptors. Proc Natl Acad Sci USA 107:1660-1665. https://doi.org/10.1073/ pnas.0907342107

Lee CH (2012) Resolvins as new fascinating drug candidates for inflammatory diseases. Arch Pharm Res 35:3-7. https://doi. org/10.1007/s12272-012-0121-z

Lee CH (2018) Epithelial-mesenchymal transition: Initiation by cues from chronic inflammatory tumor microenvironment and termination by anti-inflammatory compounds and specialized proresolving lipids. Biochem Pharmacol 158:261-273. https://doi. org/10.1016/j.bcp.2018.10.031

Lee CH, Kim JH, Lee SW (2017) The role of microRNA in pathogenesis and as markers of HCV chronic infection. Curr Drug Targets 18:756-765. https://doi.org/10.2174/138945011766616 0401125213

Lee HJ, Park MK, Lee EJ, Lee CH (2013) Resolvin D1 inhibits TGFbeta1-induced epithelial mesenchymal transition of A549 lung cancer cells via lipoxin A4 receptor/formyl peptide receptor 2 and GPR32. Int J Biochem Cell Biol 45:2801-2807. https://doi. org/10.1016/j.biocel.2013.09.018

Levy BD (2005) Lipoxins and lipoxin analogs in asthma. Prostaglandins Leukot Essent Fatty Acids 73:231-237. https://doi. org/10.1016/j.plefa.2005.05.010

Liao Z, Dong J, Wu W, Yang T, Wang T, Guo L, Chen L, Xu D, Wen F (2012) Resolvin D1 attenuates inflammation in lipopolysaccharide-induced acute lung injury through a process involving the PPARgamma/NF-kappaB pathway. Respir Res 13:110. https:// doi.org/10.1186/1465-9921-13-110

Lin Q, Fang D, Hou X, Le Y, Fang J, Wen F, Gong W, Chen K, Wang JM, Su SB (2011) HCV peptide (C5A), an amphipathic alphahelical peptide of hepatitis virus $\mathrm{C}$, is an activator of $\mathrm{N}$-formyl peptide receptor in human phagocytes. J Immunol 186:20872094. https://doi.org/10.4049/jimmunol.1002340

Lopes JP, Morato X, Souza C, Pinhal C, Machado NJ, Canas PM, Silva HB, Stagljar I, Gandia J, Fernandez-Duenas V, Lujan R, Cunha RA, Ciruela F (2015) The role of parkinson's disease-associated receptor GPR37 in the hippocampus: functional interplay with the adenosinergic system. J Neurochem 134:135-146. https:// doi.org/10.1111/jnc.13109

Luangsay S, Wittamer V, Bondue B, De Henau O, Rouger L, Brait M, Franssen JD, De Nadai P, Huaux F, Parmentier M (2009) Mouse ChemR23 is expressed in dendritic cell subsets and macrophages, and mediates an anti-inflammatory activity of chemerin in a lung disease model. J Immunol 183:6489-6499. https://doi. org/10.4049/jimmunol.0901037

Lukiw WJ, Cui JG, Marcheselli VL, Bodker M, Botkjaer A, Gotlinger K, Serhan CN, Bazan NG (2005) A role for docosahexaenoic acid-derived neuroprotectin D1 in neural cell survival and Alzheimer disease. J Clin Invest 115:2774-2783. https://doi. org/10.1172/JCI25420 
Maddox JF, Serhan CN (1996) Lipoxin A4 and B4 are potent stimuli for human monocyte migration and adhesion: selective inactivation by dehydrogenation and reduction. J Exp Med 183:137-146. https://doi.org/10.1084/jem.183.1.137

Maderna P, Cottell DC, Toivonen T, Dufton N, Dalli J, Perretti M, Godson C (2010) FPR2/ALX receptor expression and internalization are critical for lipoxin A4 and annexin-derived peptidestimulated phagocytosis. FASEB J 24:4240-4249. https://doi. org/10.1096/fj.10-159913

Marazziti D, Golini E, Gallo A, Lombardi MS, Matteoni R, TocchiniValentini GP (1997) Cloning of GPR37, a gene located on chromosome 7 encoding a putative G-protein-coupled peptide receptor, from a human frontal brain EST library. Genomics 45:68-77. https://doi.org/10.1006/geno.1997.4900

Marazziti D, Mandillo S, Di Pietro C, Golini E, Matteoni R, TocchiniValentini GP (2007) GPR37 associates with the dopamine transporter to modulate dopamine uptake and behavioral responses to dopaminergic drugs. Proc Natl Acad Sci USA 104:9846-9851. https://doi.org/10.1073/pnas.0703368104

Martensson UE, Fenyo EM, Olde B, Owman C (2006) Characterization of the human chemerin receptor-ChemR23/CMKLR1as co-receptor for human and simian immunodeficiency virus infection, and identification of virus-binding receptor domains. Virology 355:6-17. https://doi.org/10.1016/j.virol.2006.07.010

Mccrary MR, Jiang MQ, Giddens MM, Zhang JY, Owino S, Wei ZZ, Zhong W, Gu X, Xin H, Hall RA, Wei L, Yu SP (2019) Protective effects of GPR37 via regulation of inflammation and multiple cell death pathways after ischemic stroke in mice. FASEB J 33:10680-10691. https://doi.org/10.1096/fj.201900070R

Mchugh D (2012) GPR18 in microglia: implications for the CNS and endocannabinoid system signalling. Br J Pharmacol 167:15751582. https://doi.org/10.1111/j.1476-5381.2012.02019.x

Meder W, Wendland M, Busmann A, Kutzleb C, Spodsberg N, John H, Richter R, Schleuder D, Meyer M, Forssmann WG (2003) Characterization of human circulating TIG2 as a ligand for the orphan receptor ChemR23. FEBS Lett 555:495-499. https://doi. org/10.1016/s0014-5793(03)01312-7

Morita M, Kuba K, Ichikawa A, Nakayama M, Katahira J, Iwamoto R, Watanebe T, Sakabe S, Daidoji T, Nakamura S, Kadowaki A, Ohto T, Nakanishi H, Taguchi R, Nakaya T, Murakami M, Yoneda Y, Arai H, Kawaoka Y, Penninger JM, Arita M, Imai Y (2013) The lipid mediator protectin D1 inhibits influenza virus replication and improves severe influenza. Cell 153:112-125. https://doi.org/10.1016/j.cell.2013.02.027

Nedellec R, Coetzer M, Shimizu N, Hoshino H, Polonis VR, Morris L, Martensson UE, Binley J, Overbaugh J, Mosier DE (2009) Virus entry via the alternative coreceptors CCR3 and FPRL1 differs by human immunodeficiency virus type 1 subtype. J Virol 83:8353-8363. https://doi.org/10.1128/JVI.00780-09

Ng S, Cowling BJ, Fang VJ, Chan KH, Ip DK, Cheng CK, Uyeki TM, Houck PM, Peiris M, J. S., and Leung GM (2010) Effects of oseltamivir treatment on duration of clinical illness and viral shedding and household transmission of influenza virus. Clin Infect Dis 50:707-714. https://doi.org/10.1086/650458

Norling LV, Dalli J, Flower RJ, Serhan CN, Perretti M (2012) Resolvin D1 limits polymorphonuclear leukocyte recruitment to inflammatory loci: receptor-dependent actions. Arterioscler Thromb Vasc Biol 32:1970-1978. https://doi.org/10.1161/ATVBA HA.112.249508

Offertaler L, Mo FM, Batkai S, Liu J, Begg M, Razdan RK, Martin BR, Bukoski RD, Kunos G (2003) Selective ligands and cellular effectors of a $G$ protein-coupled endothelial cannabinoid receptor. Mol Pharmacol 63:699-705. https://doi.org/10.1124/ mol.63.3.699

Oh SF, Dona M, Fredman G, Krishnamoorthy S, Irimia D, Serhan CN (2012) Resolvin E2 formation and impact in inflammation resolution. J Immunol 188:4527-4534. https://doi.org/10.4049/ jimmunol.1103652

Oh SF, Pillai PS, Recchiuti A, Yang R, Serhan CN (2011) Pro-resolving actions and stereoselective biosynthesis of $18 \mathrm{~S}$ E-series resolvins in human leukocytes and murine inflammation. J Clin Invest 121:569-581. https://doi.org/10.1172/JCI42545

Pal A, Gowdy KM, Oestreich KJ, Beck M, Shaikh SR (2020) Obesitydriven deficiencies of specialized pro-resolving mediators may drive adverse outcomes during SARS-CoV-2 infection. Front Immunol 11:1997. https://doi.org/10.3389/fimmu.2020.01997

Panigrahy D, Gilligan MM, Huang S, Gartung A, Cortes-Puch I, Sime PJ, Phipps RP, Serhan CN, Hammock BD (2020) Inflammation resolution: a dual-pronged approach to averting cytokine storms in COVID-19? Cancer Metastasis Rev 39:337-340. https://doi. org/10.1007/s10555-020-09889-4

Park CK (2015) Maresin 1 inhibits TRPV1 in temporomandibular joint-related trigeminal nociceptive neurons and TMJ inflammation-induced synaptic plasticity in the trigeminal nucleus. Mediators Inflamm 2015:275126. https://doi.org/10.1155/2015/275126

Park J, Langmead CJ, Riddy DM (2020) New Advances in Targeting the Resolution of Inflammation: Implications for Specialized Pro-Resolving Mediator GPCR Drug Discovery. ACS Pharmacol Transl Sci 3:88-106. https://doi.org/10.1021/acsptsci.9b00075

Pham TL, He J, Kakazu AH, Calandria J, Do KV, Nshimiyimana R, Petasis NA, Bazan HEP, Bazan NG (2020) Elovanoid-N32 or RvD6-isomer decrease ACE2 and binding of S protein RBD after injury or INFgamma in the eye. Res Sq. https://doi.org/10.21203 /rs.3.rs-55764/v1

Planaguma A, Pfeffer MA, Rubin G, Croze R, Uddin M, Serhan CN, Levy BD (2010) Lovastatin decreases acute mucosal inflammation via 15-epi-lipoxin A4. Mucosal Immunol 3:270-279. https ://doi.org/10.1038/mi.2009.141

Powell MK, Benkova K, Selinger P, Dogosi M, Kinkorova Lunackova I, Koutnikova H, Lastikova J, Roubickova A, Spurkova Z, Laclova L, Eis V, Sach J, Heneberg P (2016) Opportunistic Infections in HIV-Infected Patients Differ Strongly in Frequencies and Spectra between Patients with Low CD4 + Cell Counts Examined Postmortem and Compensated Patients Examined Antemortem Irrespective of the HAART Era. PLoS One 11:e0162704. https ://doi.org/10.1371/journal.pone.0162704

Psychogios N, Hau DD, Peng J, Guo AC, Mandal R, Bouatra S, Sinelnikov I, Krishnamurthy R, Eisner R, Gautam B, Young N, Xia J, Knox C, Dong E, Huang P, Hollander Z, Pedersen TL, Smith SR, Bamforth F, Greiner R, Mcmanus B, Newman JW, Goodfriend T, Wishart DS (2011) The human serum metabolome. PLoS One 6:e16957. https://doi.org/10.1371/journal.pone.0016957

Rajasagi NK, Bhela S, Varanasi SK, Rouse BT (2017) Frontline Science: Aspirin-triggered resolvin D1 controls herpes simplex virus-induced corneal immunopathology. J Leukoc Biol 102:1159-1171. https://doi.org/10.1189/jlb.3HI1216-511RR

Rajasagi NK, Reddy PB, Mulik S, Gjorstrup P, Rouse BT (2013) Neuroprotectin D1 reduces the severity of herpes simplex virusinduced corneal immunopathology. Invest Ophthalmol Vis Sci 54:6269-6279. https://doi.org/10.1167/iovs.13-12152

Rajasagi NK, Reddy PB, Suryawanshi A, Mulik S, Gjorstrup P, Rouse BT (2011) Controlling herpes simplex virus-induced ocular inflammatory lesions with the lipid-derived mediator resolvin E1. J Immunol 186:1735-1746. https://doi.org/10.4049/jimmu nol.1003456

Ramon S, Bancos S, Serhan CN, Phipps RP (2014) Lipoxin A(4) modulates adaptive immunity by decreasing memory B-cell responses via an ALX/FPR2-dependent mechanism. Eur J Immunol 44:357-369. https://doi.org/10.1002/eji.201343316

Read JF, Bosco A (2020) Decoding susceptibility to respiratory viral infections and asthma inception in children. Int J Mol Sci. https ://doi.org/10.3390/ijms21176372 
Reville K, Crean JK, Vivers S, Dransfield I, Godson C (2006) Lipoxin A4 redistributes myosin IIA and $\mathrm{Cdc} 42$ in macrophages: implications for phagocytosis of apoptotic leukocytes. J Immunol 176:1878-1888. https://doi.org/10.4049/ jimmunol.176.3.1878

Richardson JY, Ottolini MG, Pletneva L, Boukhvalova M, Zhang S, Vogel SN, Prince GA, Blanco JC (2005) Respiratory syncytial virus (RSV) infection induces cyclooxygenase 2: a potential target for RSV therapy. J Immunol 174:4356-4364. https://doi. org/10.4049/jimmunol.174.7.4356

Rodriguez AR, Spur BW (2020) First total syntheses of the proresolving lipid mediators $7(\mathrm{~S}), 13(\mathrm{R}), 20(\mathrm{~S})$-Resolvin T1 and 7(S),13(R)-Resolvin T4. Tetrahedron Lett. https://doi. org/10.1016/j.tetlet.2019.151473

Rodriguez AR, Spur BW (2020) First total synthesis of the proresolving lipid mediator $7(\mathrm{~S}), 12(\mathrm{R}), 13(\mathrm{~S})$-Resolvin $\mathrm{T} 2$ and its 13(R)-epimer. Tetrahedron Lett. https://doi.org/10.1016/j.tetle t.2020.151857

Rogero MM, Leao MC, Santana TM, Pimentel M, Carlini GCG, Silveira D, Goncalves TFF, R. C., and Castro IA (2020) Potential benefits and risks of omega-3 fatty acids supplementation to patients with COVID-19. Free Radic Biol Med 156:190-199. https://doi.org/10.1016/j.freeradbiomed.2020.07.005

Romano M, Cianci E, Simiele F, Recchiuti A (2015) Lipoxins and aspirin-triggered lipoxins in resolution of inflammation. Eur J Pharmacol 760:49-63. https://doi.org/10.1016/j.ejphar.2015.03.083

Rusyn I, Lemon SM (2014) Mechanisms of HCV-induced liver cancer: what did we learn from in vitro and animal studies? Cancer Lett 345:210-215. https://doi.org/10.1016/j.canlet.2013.06.028

Ryu W-S (2017) Virus life cycle. Mol Virol Hum Pathog Viruses 31:31-45. https://doi.org/10.1016/C2013-0-15172-0

Samson, M., Edinger, A. L., Stordeur, P., Rucker, J., Verhasselt, V., Sharron, M., Govaerts, C., Mollereau, C., Vassart, G., Doms, R. W., and Parmentier, M. (1998) ChemR23, a putative chemoattractant receptor, is expressed in monocyte-derived dendritic cells and macrophages and is a coreceptor for SIV and some primary HIV-1 strains. Eur J Immunol 28: 1689-1700. https:// doi.org/10.1002/(SICI)1521-4141(199805)28:05<1689::AIDIMMU1689>3.0.CO;2-I.

Sanceau JY, Maltais R, Poirier D, Marette A (2019) Total Synthesis of the Antidiabetic (Type 2) Lipid Mediator Protectin DX/PDX. J Org Chem 84:495-505. https://doi.org/10.1021/acs.joc.8b01973

Sansbury BE, Spite M (2016) Resolution of Acute Inflammation and the Role of Resolvins in Immunity, Thrombosis, and Vascular Biology. Circ Res 119:113-130. https://doi.org/10.1161/CIRCR ESAHA.116.307308

Schmid M, Gemperle C, Rimann N, Hersberger M (2016) Resolvin D1 polarizes primary human macrophages toward a proresolution phenotype through GPR32. J Immunol 196:3429-3437. https:// doi.org/10.4049/jimmunol.1501701

Schweitzer JW, Justice NA (2020) Respiratory syncytial virus infection (RSV). StatPearls, Treasure Island (FL)

Serhan CN, Chiang N, Dalli J, Levy BD (2014) Lipid mediators in the resolution of inflammation. Cold Spring Harb Perspect Biol 7:a016311. https://doi.org/10.1101/cshperspect.a016311

Serhan CN, Clish CB, Brannon J, Colgan SP, Chiang N, Gronert K (2000) Novel functional sets of lipid-derived mediators with antiinflammatory actions generated from omega-3 fatty acids via cyclooxygenase 2-nonsteroidal antiinflammatory drugs and transcellular processing. J Exp Med 192:1197-1204. https://doi. org/10.1084/jem.192.8.1197

Serhan CN, Hong S, Gronert K, Colgan SP, Devchand PR, Mirick G, Moussignac RL (2002) Resolvins: a family of bioactive products of omega-3 fatty acid transformation circuits initiated by aspirin treatment that counter proinflammation signals. J Exp Med 196:1025-1037. https://doi.org/10.1084/jem.20020760
Serhan CN, Savill J (2005) Resolution of inflammation: the beginning programs the end. Nat Immunol 6:1191-1197. https://doi. org/10.1038/ni1276

Shimizu N, Tanaka A, Mori T, Ohtsuki T, Hoque A, Jinno-Oue A, Apichartpiyakul C, Kusagawa S, Takebe Y, Hoshino H (2008) A formylpeptide receptor, FPRL1, acts as an efficient coreceptor for primary isolates of human immunodeficiency virus. Retrovirology 5:52. https://doi.org/10.1186/1742-4690-5-52

Shinohara M, Mirakaj V, Serhan CN (2012) Functional metabolomics reveals novel active products in the DHA metabolome. Front Immunol 3:81. https://doi.org/10.3389/fimmu.2012.00081

Shirey KA, Lai W, Pletneva LM, Karp CL, Divanovic S, Blanco JC, Vogel SN (2014) Role of the lipoxygenase pathway in RSVinduced alternatively activated macrophages leading to resolution of lung pathology. Mucosal Immunol 7:549-557. https://doi. org/10.1038/mi.2013.71

Shirey KA, Pletneva LM, Puche AC, Keegan AD, Prince GA, Blanco JC, Vogel SN (2010) Control of RSV-induced lung injury by alternatively activated macrophages is IL-4R alpha-, TLR4-, and IFN-beta-dependent. Mucosal Immunol 3:291-300. https://doi. org/10.1038/mi.2010.6

Takano T, Fiore S, Maddox JF, Brady HR, Petasis NA, Serhan CN (1997) Aspirin-triggered 15-epi-lipoxin A4 (LXA4) and LXA4 stable analogues are potent inhibitors of acute inflammation: evidence for anti-inflammatory receptors. J Exp Med 185:16931704. https://doi.org/10.1084/jem.185.9.1693

Tam VC, Quehenberger O, Oshansky CM, Suen R, Armando AM, Treuting PM, Thomas PG, Dennis EA, Aderem A (2013) Lipidomic profiling of influenza infection identifies mediators that induce and resolve inflammation. Cell 154:213-227. https://doi. org/10.1016/j.cell.2013.05.052

Tcherniuk S, Cenac N, Comte M, Frouard J, Errazuriz-Cerda E, Galabov A, Morange PE, Vergnolle N, Si-Tahar M, Alessi MC, Riteau B (2016) Formyl Peptide Receptor 2 Plays a Deleterious Role During Influenza A Virus Infections. J Infect Dis 214:237247. https://doi.org/10.1093/infdis/jiw127

Torrinhas RS, Calder PC, Lemos GO, Waitzberg DL (2020) Parenteral fish oil: an adjuvant pharmacotherapy for coronavirus disease 2019? Nutrition 81:110900. https://doi.org/10.1016/j. nut.2020.110900

Unno Y, Sato Y, Fukuda H, Ishimura K, Ikeda H, Watanabe M, TanshoNagakawa S, Ubagai T, Shuto S, Ono Y (2018) Resolvin E1, but not resolvins E2 and E3, promotes fMLF-induced ROS generation in human neutrophils. FEBS Lett 592:2706-2715. https:// doi.org/10.1002/1873-3468.13215

Wan M, Godson C, Guiry PJ, Agerberth B, Haeggstrom JZ (2011) Leukotriene B4/antimicrobial peptide LL-37 proinflammatory circuits are mediated by BLT1 and FPR2/ALX and are counterregulated by lipoxin A4 and resolvin E1. FASEB J 25:16971705. https://doi.org/10.1096/fj.10-175687

Wang CW, Colas RA, Dalli J, Arnardottir HH, Nguyen D, Hasturk H, Chiang N, Van Dyke TE, Serhan CN (2015) Maresin 1 biosynthesis and proresolving anti-infective functions with humanlocalized aggressive periodontitis leukocytes. Infect Immun 84:658-665. https://doi.org/10.1128/IAI.01131-15

Wang H, Anthony D, Selemidis S, Vlahos R, Bozinovski S (2018) Resolving Viral-Induced Secondary Bacterial Infection in COPD: A Concise Review. Front Immunol 9:2345. https://doi. org/10.3389/fimmu.2018.02345

Wang H, Anthony D, Yatmaz S, Wijburg O, Satzke C, Levy B, Vlahos R, Bozinovski S (2017) Aspirin-triggered resolvin D1 reduces pneumococcal lung infection and inflammation in a viral and bacterial coinfection pneumonia model. Clin Sci (Lond) 131:2347-2362. https://doi.org/10.1042/CS20171006

Wang X, Sumida H, Cyster JG (2014) GPR 18 is required for a normal CD8alphaalpha intestinal intraepithelial 
lymphocyte compartment. J Exp Med 211:2351-2359. https:// doi.org/10.1084/jem.20140646

Winkler JW, Orr SK, Dalli J, Cheng CY, Sanger JM, Chiang N, Petasis NA, Serhan CN (2016) Resolvin D4 stereoassignment and its novel actions in host protection and bacterial clearance. Sci Rep 6:18972. https://doi.org/10.1038/srep18972

Wittamer V, Gregoire F, Robberecht P, Vassart G, Communi D, Parmentier M (2004) The C-terminal nonapeptide of mature chemerin activates the chemerin receptor with low nanomolar potency. J Biol Chem 279:9956-9962. https://doi.org/10.1074/ jbc.M313016200

Yang HJ, Vainshtein A, Maik-Rachline G, Peles E (2016) G proteincoupled receptor 37 is a negative regulator of oligodendrocyte differentiation and myelination. Nat Commun 7:10884. https:// doi.org/10.1038/ncomms10884

Ye RD, Cavanagh SL, Quehenberger O, Prossnitz ER, Cochrane CG (1992) Isolation of a cDNA that encodes a novel granulocyte
$\mathrm{N}$-formyl peptide receptor. Biochem Biophys Res Commun 184:582-589. https://doi.org/10.1016/0006-291x(92)90629-y

Yokomizo T, Izumi T, Chang K, Takuwa Y, Shimizu T (1997) A G-protein-coupled receptor for leukotriene B4 that mediates chemotaxis. Nature 387:620-624. https://doi.org/10.1038/42506

Zhao Y, Calon F, Julien C, Winkler JW, Petasis NA, Lukiw WJ, Bazan NG (2011) Docosahexaenoic acid-derived neuroprotectin D1 induces neuronal survival via secretase- and PPARgammamediated mechanisms in Alzheimer's disease models. PLoS One 6:e15816. https://doi.org/10.1371/journal.pone.0015816

Publisher's Note Springer Nature remains neutral with regard to jurisdictional claims in published maps and institutional affiliations. 